CZASOPISMO INŻYNIERII LADOWEJ, ŚRODOWISKA I ARCHITEKTURY

JOURNAL OF CIVIL ENGINEERING, ENVIRONMENT AND ARCHITECTURE

JCEEA, t. XXXII, z. 62 (3/II/15), lipiec-wrzesień 2015, s. 105-117

\author{
Marcin GÓRSKI \\ Aleksander KOZLOWSKI ${ }^{2}$ \\ Tomasz KOZLOWSKI ${ }^{3}$ \\ Pawel LUDERA ${ }^{4}$
}

\title{
ANALIZA UKLADU STĘŻAJĄCEGO BUDYNKU WYSOKOŚCIOWEGO O KONSTRUKCJI BETONOWEJ
}

\begin{abstract}
Omówiono stosowane obecnie układy stężające budynków wysokich, ze szczególnym uwzględnieniem budynków o konstrukcji betonowej. Na przykładzie budynku o wysokości $136 \mathrm{~m}$ przeanalizowano kształtowanie układu stężającego. Analizie poddano wpływ ukształtowania trzonu budynku, ścian i słupów współpracujących z trzonem na sztywność poprzeczną budynku. Analizy wykonano z wykorzystaniem programu ROBOT.
\end{abstract}

Słowa kluczowe: budynek wysokościowy, układ stężający, sztywność budynku,

\section{Wstęp}

Początek ery budynków wysokich sięga końca XIX wieku, kiedy zaczęto stosować szkieletowy układ nośny budynków. W układzie tym szkielet budynku złożony z belek, rygli, słupów i stężeń przenosi wszystkie obciążenia grawitacyjne oraz oddziaływanie wiatru, a ściany mają przeznaczenie osłonowe. Pierwsze takie budynki wzniesiono w USA, w Chicago a potem w Nowym Yorku. Powstały wtedy takie, istniejące do dziś budynki, jak Reliance Building, Chrysler Building $(319 \mathrm{~m})$, Empire State Building (381 m). Wszystkie te budynki powstały jeszcze przed drugą woją światową.

Kolejną falą realizacji budynków wysokich były zbudowane w latach 60 i 70. XX wieku w USA budynki wysokościowe: John Hancock Center $(343,0 \mathrm{~m})$ w Chicago, bliźniacze wieże World Trade Center (415,0 i 417,0 m) w Nowym Jorku, Sears Tower, obecnie Willis Tower (442,0 m) w Chicago.

\footnotetext{
${ }^{1}$ Autor do korespondencji: Marcin Górski, Politechnika Rzeszowska, mgorski@prz.edu.pl.

2 Aleksander Kozłowski, Politechnika Rzeszowska, kozlowsk@prz.edu.pl

${ }^{3}$ Tomasz Kozłowski, Politechnika Rzeszowska, tkozlowski@prz.edu.pl

${ }^{4}$ Paweł Ludera, P\&A,
} 
Budynki te mają konstrukcję stalową. Era stosowania konstrukcji stalowych w budynkach wysokich trwała do końca lat 90-tych XX wieku, kiedy to zaczęto stosować konstrukcje zespolone, stalowo-betonowe, np. Petronas Towers (452,0 m), Taipei 101 o wysokości 509,0 m.

Obecnie większość budynków wysokich, w tym najwyższy budynek na świecie, Burj Khalifa o wysokości $828 \mathrm{~m}$, ma konstrukcję betonową.

\section{Układy stężające budynków}

\subsection{Budynki o konstrukcji stalowej}

Układy stężające budynków o konstrukcji stalowej można podzielić na płaskie i przestrzenne.

W układach płaskich stosuje się:

- układy nośne ramowe, w których wydzielone ramy przenoszą przypadające na nie obciążenia pionowe i poziome,

- układy wieloprzegubowe o stężeniach kratowych, w których w wybranych, uzgodnionych $\mathrm{z}$ architektem osiach, stosuje się układy stężające w postaci wspornikowych kratownic, przenoszących obciążenia poziome z całego budynku; pozostała część konstrukcji budynku przenosi wyłącznie obciążenia pionowe, grawitacyjne,

- układy wieloprzegubowe o stężeniach tarczowych, w których w miejsce wspornikowych kratownic stosuje się wspornikowe ściany betonowe, przenoszące obciążenia poziome,

- układy mieszane, ramowo-kratowe lub ramowo-tarczowe.

W układach przestrzennych stosuje się:

- układy nośne trzonowe, w których wszystkie obciążenia poziome przenosi trzon wykonany najczęściej wokół klatek schodowych i wind istniejących w budynku,

- układy wieloprzegubowe stężone przestrzennymi ramami kratowymi (angielska nazwa outriggers), gdzie z płaskich, pionowych wsporników kratowych wypuszczane są wsporniki łączone następnie z otokiem wokół obwodu budynku. Powoduje to uprzestrzennienie konstrukcji, tzn. wszystkie słupy, nawet te poza układem stężającym wciągane są do współpracy,

- układy powłokowe, w których konstrukcja układu stężającego zlokalizowana jest na obwodzie konstrukcji, w postaci gęsto rozmieszczonych słupów i rygli co tworzy tzw. rurę perforowaną,

- systemy mega konstrukcji, o ogromnych słupach zlokalizowanych w narożach budynku.

Zestawienie układów stężających stosowanych w budynkach o konstrukcji stalowej przedstawiono $\mathrm{w}$ tabeli 1. 
Tabela 1. Układy stężające stosowane w budynkach o konstrukcji stalowej

Table 1. Lateral load-resisting systems applied in steel buildings

\begin{tabular}{|c|c|c|}
\hline \multicolumn{2}{|c|}{ Uklady stężające } & \multirow{2}{*}{$\begin{array}{l}\text { Liczba kondygnacji, } \\
\text { wysokość budynku }\end{array}$} \\
\hline \multicolumn{2}{|l|}{ 1. Płaskie } & \\
\hline \multirow[t]{2}{*}{ 1.1. Ramowy } & węzły sztywne & $\begin{array}{l}\text { do } 10 \text { kond., } \\
\mathrm{H}<2 \text { B }\end{array}$ \\
\hline & węzły podatne & $\mathrm{H}<1,5 \mathrm{~B}$ \\
\hline \multicolumn{2}{|l|}{ 1.2. Kratowy } & do 30 kond. \\
\hline \multirow[t]{2}{*}{ 1.3. Tarczowy } & ściany murowane & do 6 kond. \\
\hline & ściany żelbetowe & do 30 kond. \\
\hline \multicolumn{2}{|l|}{ 1.4. Mieszane } & do 40 kond. \\
\hline \multicolumn{3}{|l|}{ 2. Przestrzenne } \\
\hline \multicolumn{2}{|l|}{ 2.1. Trzonowe } & do 40 kond. \\
\hline \multicolumn{2}{|c|}{ 2.2. Z przestrzennymi ramami kratowymi } & do 60 kond. \\
\hline \multicolumn{2}{|c|}{ 2.3. Powłokowe } & $50-110$ kond. \\
\hline \multicolumn{2}{|c|}{ 2.4. Megakonstrukcje } & do 150 kond. \\
\hline
\end{tabular}

\subsection{Budynki o konstrukcji betonowej}

W budynkach betonowych stosuje się, podobnie jak w stalowych, układy stężające $\mathrm{w}$ postaci ram samostatecznych, przykładowo prefabrykowane ramy typu $\mathrm{H}$ stosowane w latach 70-tych XX wieku, lub obecnie projektowane ramy monolityczne. Jednak w większości budynków betonowych stosuje się układy stężające tarczowe (ścienne) oraz trzonowe.

W niskich budynkach o konstrukcji betonowej najczęściej stosuje się układy stężające wykorzystujące istniejące w budynku elementy, jak ściany, trzony klatek schodowych i dźwigów osobowych. Takie ukształtowanie budynku prowadzi do bardzo ekonomicznych rozwiązań: obciążenie poziome, czyli głównie oddziaływanie wiatru, przenoszone jest przez sztywne tarcze stropowe na pionowe wsporniki w postaci tarcz ściennych usytuowanych równoległe do działających obciążeń, lub wspornikowe rury o wielkich wymiarach obejmujące elementy komunikacji pionowej. Pozostała część konstrukcji budynku przenosi jedynie obciążenia pionowe.

W wyższych budynkach wykorzystuje się współpracę trzonu centralnego $z$ istniejącymi ścianami betonowych $\mathrm{i} /$ lub ze słupami umieszczonymi na obwodzie budynku. Powoduje to istotne zwiększenie sztywności budynku. Takie rozwiązanie zastosowano m.in. w najwyższym budynku świata Burj Khalifa, w którym trzon centralny o kształcie sześcioboku współpracuje ze ścianami 
"młotkowymi" odbiegającymi w trzech kierunkach od trzonu oraz ze słupami usytuowanymi na obrysie budynku.

Szczegółowy opis stosowanych układów nośnych, w tym stężających, budynków wysokich można znaleźć m.in. w [1-6].

\section{Opis analizowanego budynku}

Kompleks budynków zaprojektowano w centrum Rzeszowa na terasie rzeki Wisłok. Kompleks składa się z podstawowego zespołu budynków o funkcji handlowo-usługowo-biurowej i mieszkalnej wielorodzinnej z garażem wielopoziomowym, uzupełnionych o zespoły miejsc postojowych stanowiących odrębne elementy konstrukcyjnie.

Zespół budynków jest podzielony pod względem konstrukcyjnym na następujące elementy:

- wieża W - budynek wysokościowy o dwóch kondygnacjach garaży, trzech kondygnacjach o funkcji handlowo-usługowo-biurowej oraz 34 kondygnacjach o funkcji mieszkalnej (łącznie 39 kondygnacji),

- wieża $\mathrm{N}$ budynek wysokościowy o dwóch kondygnacjach garaży, trzech kondygnacjach o funkcji handlowo-usługowo-biurowej oraz 16 kondygnacjach o funkcji mieszkalnej ( łącznie 21 kondygnacji),

- zabudowa uzupełniająca U pomiędzy budynkami wysokościowymi - budynki trzykondygnacyjne o funkcji handlowo-usługowobiurowej z dwoma kondygnacjami garaży.

Budynki pomiędzy sobą są całkowicie zdylatowane łącznie z fundamentami ze względu na rożny rodzaj posadowienia budynków i zróżnicowane obciążenia fundamentów.

Wszystkie budynki wchodzące w skład zespołu budynków są budynkami o konstrukcji żelbetowej.

Budynek wysokościowy (wieża W) zaprojektowano o konstrukcji żelbetowej z centralnym trzonem żelbetowym złożonym ze ścian o grubości $25 \mathrm{~cm}$ : wewnętrznych korytarzy, ścian obudowy klatek schodowych i ścian szybów windowych. Dodatkowo częścią trzonu są żelbetowe kanały wentylacyjne biegnące przez całą wysokości budynku. Konstrukcja budynku poza trzonem komunikacyjnym zaprojektowana jest jako szkielet żelbetowy złożony $\mathrm{z}$ zewnętrznych słupów żelbetowych o zmiennych przekrojach połączonych z trzonem płytami stropowymi bezbelkowymi gr. $22 \mathrm{~cm}$. Wymiary słupów zmieniają się od $80 \times 80 \mathrm{~cm}$ w kondygnacjach najniższych, przez 70x70 w pośrednich, do $60 \times 60 \mathrm{~cm} w$ kondygnacjach najwyższych. Słupy zaprojektowano z betonu klasy C35/45 w kondygnacjach -2 do $+4, \mathrm{C} 30 / 37 \mathrm{w}$ kondygnacjach +5 do +20 
i C25/30 w najwyższych. Stropy na poszczególnych kondygnacjach zaprojektowano jako płytowe, bezbelkowe, żelbetowe o podstawowej grubości $22 \mathrm{~cm}$ (lokalnie 20 i $15 \mathrm{~cm}$ ), z betony klasy $\mathrm{C} 25 / 30$, z przewieszeniami poza obrys słupów, ze względu na geometryczne ukształtowanie architektury budynku na poszczególnych kondygnacjach. Dodatkowe usztywnienie obu wież stanowią ściany żelbetowe gr. $25 \mathrm{~cm}$ łączące słupy z trzonem w co drugim układzie nośnym. Posadowienie budynku zaprojektowano na płycie fundamentowej o gr. $140 \mathrm{~cm}$ pracującej w układzie skrzyniowym (dodatkowa kondygnacja techniczna) posadowionej na palach żelbetowych.

Podstawowe dane geometryczne budynku - łączna wysokość konstrukcji budynku $136 \mathrm{~m}$, w tym wysokość ponad projektowany poziom terenu 132,3 m; średni wymiar rzutu kondygnacji mieszkalnej 27,7 x 27,7 m, wymiar nośnego trzonu komunikacyjnego 17,7 x 10,6 m. Na dachu budynku zaprojektowano dodatkowo wieżę stalową o wysokości $26 \mathrm{~m}$.

Przekrój poprzeczny budynku pokazano na rys. 1 .

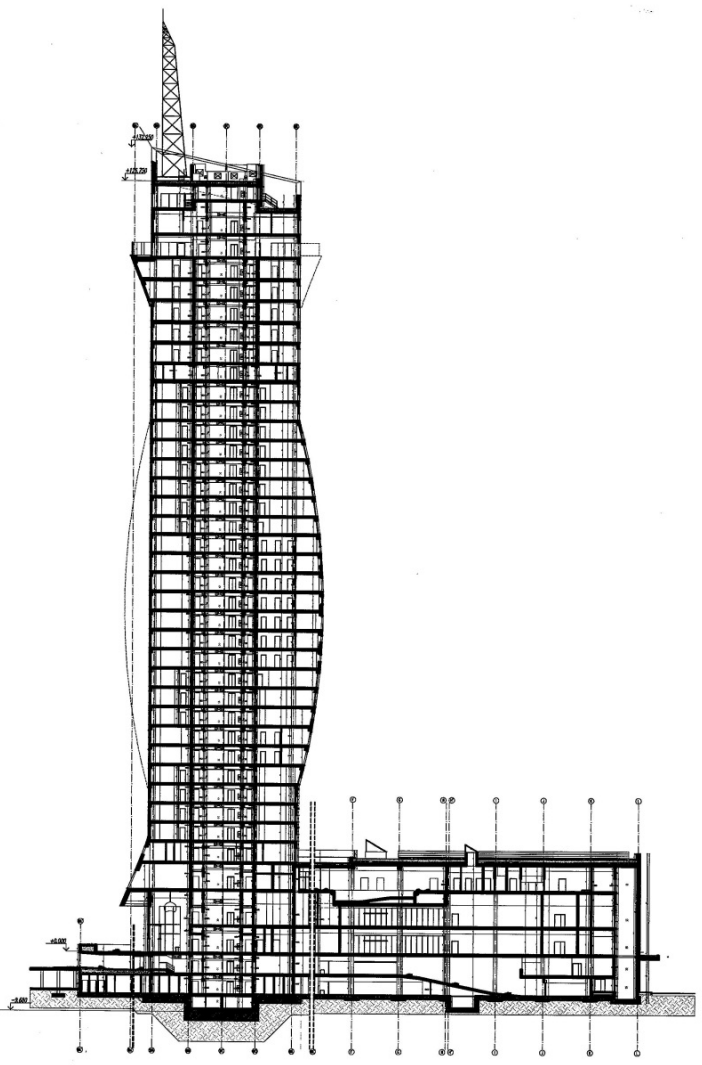

Rys. 1. Przekrój poprzeczny budynku wysokościowego W

Fig. 1. Cross section of $\mathrm{W}$ building 


\section{Analiza układu stężającego}

Obiekt został zamodelowany w programie Autodesk Robot Structural Analysis Professional [7] przy użyciu elementów prętowych (belki i słupy) oraz powłokowych, 3 i 4 - węzłowych o boku nie większym niż $0,5 \mathrm{~m}$ (ściany i stropy). Widok modelu przedstawiono na rys. 2. Model składał się łącznie z ponad 280000 elementów skończonych oraz ponad 240000 węzłów (rys. 3). Posadowienie budynku przewidziano na fundamencie zespolonym skrzyniowopalowym, jednak na potrzeby analizy układu stężającego przyjęto w modelu utwierdzenie płyty fundamentowej. Obciążenia do stropów (obciążenie stałe i eksploatacyjne) przyłożone były jako powierzchniowe. Oddziaływanie wiatru przyłożono jako obciążenie liniowe do krawędzi stropów. Ciężar własny elementów konstrukcji został automatycznie wygenerowany w programie.

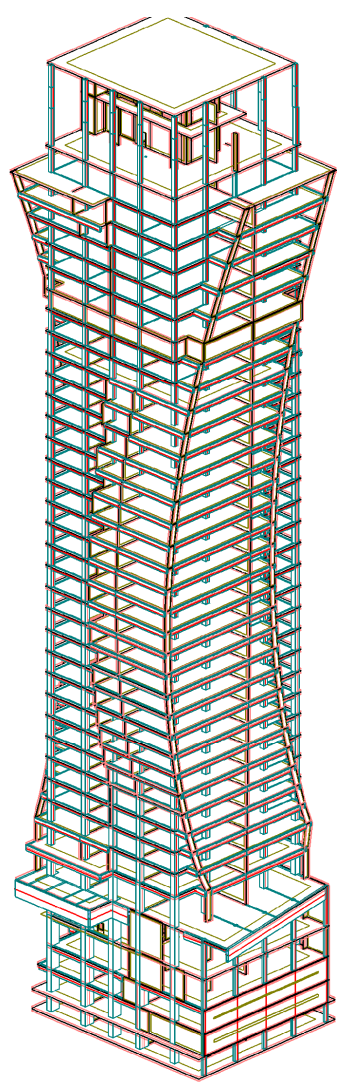

Rys. 2. Model budynku w programie Autodesk Robot

Fig. 2. Model of the building in Autodesk Robot software 


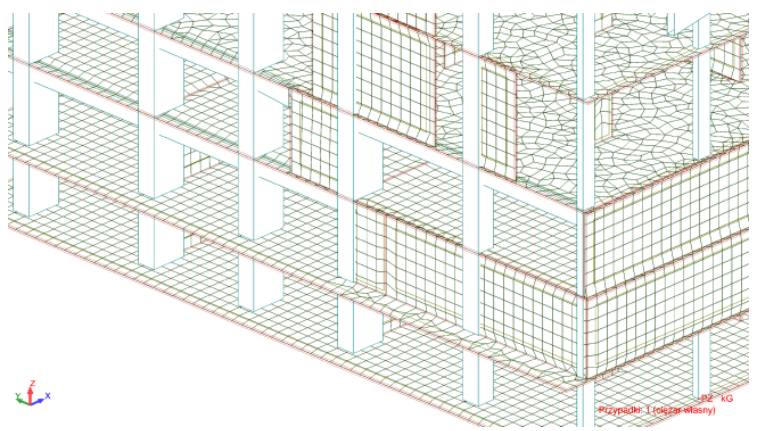

Rys. 3. Widok fragmentu modelu numerycznego wraz z siatką elementów skończonych

Fig. 3. View of a part of numerical model with mesh

Analizę układu stężającego przeprowadzono na zasadzie modyfikacji bądź usuwania z modelu kolejnych elementów konstrukcyjnych budynku w stosunku do układu wyjściowego i badanie wpływu tych zmian na sztywność obiektu oraz rozkład sił w elementach. Porównywano wychylenie wierzchołka budynku w kierunku poprzecznym, siły w słupach najniższej kondygnacji oraz naprężenia w punkcie narożnym ściany trzonu „A” (rys. 4). Dla zwiększenia czytelności analizy, wszystkie wyniki pochodzą z tej samej kombinacji obciążeń.

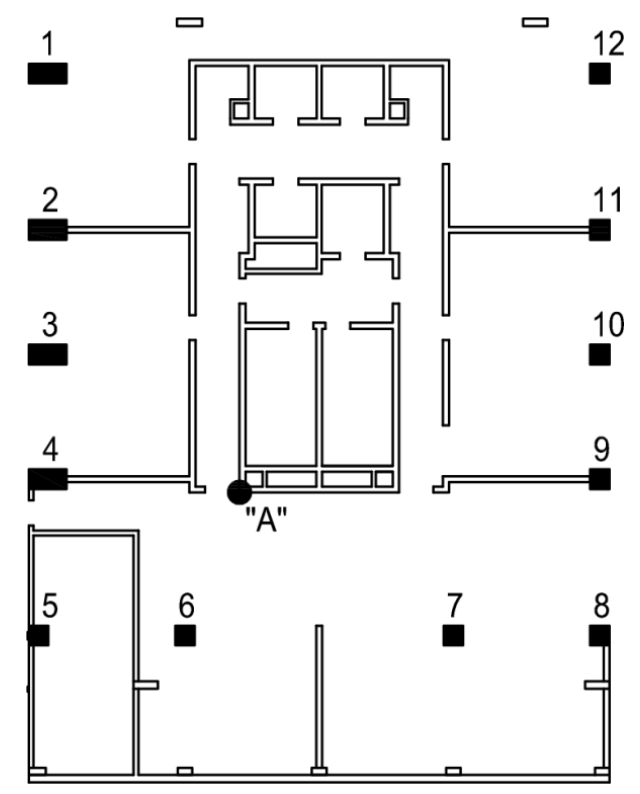

Rys. 4. Rzut elementów konstrukcyjnych najniższej kondygnacji wraz z przyjętą numeracją słupów oraz punktem „A”, z którego odczytywano naprężenia w trzonie.

Fig. 4. Floor plan of structural elements on the lowest storey with assumed numeration of the columns and the point " $\mathrm{A}$ ", where the stresses in core has been read. 
Analizie poddano następujące przypadki:

I wyjściowy układ konstrukcyjny (rys. 5),

II układ, w którym boki wszystkich słupów zostały zwiększone o $20 \mathrm{~cm}$,

III układ, w którym usunięto belki obwodowe zaprojektowane na krawędziach płyt stropowych,

IV układ bez ścian poprzecznych do trzonu budynku (rys. 6),

V układ bez ścian poprzecznych oraz belek obwodowych,

VI układ bez ścian poprzecznych oraz belek obwodowych, ale z zachowanym i rozbudowanym outriggerem na kondygnacji technicznej (rys. 7),

VII układ bez ścian poprzecznych oraz ścian do nich prostopadłych (rys. 8),

VIII układ bez ścian poprzecznych oraz słupów.

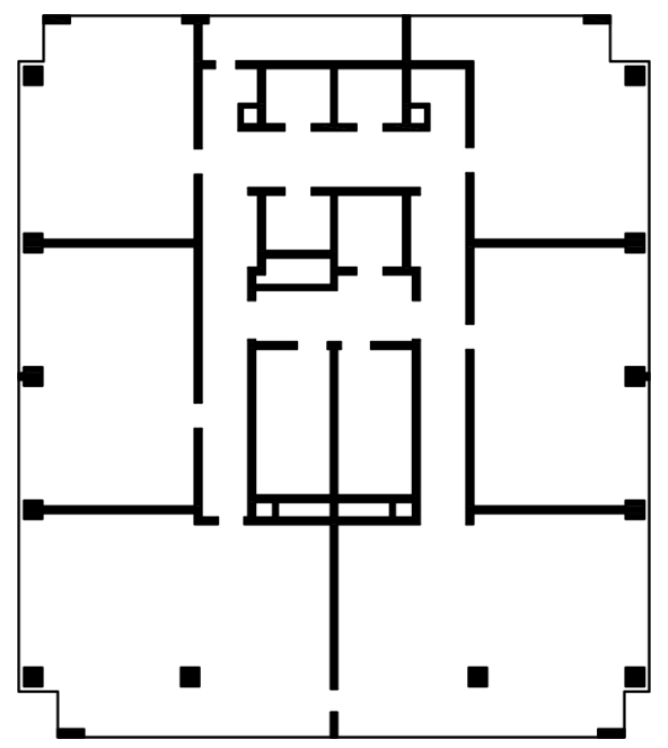

Rys. 5. Rzut wyjściowego układu konstrukcyjnego

Fig. 5. Floor plan of initial structural scheme 


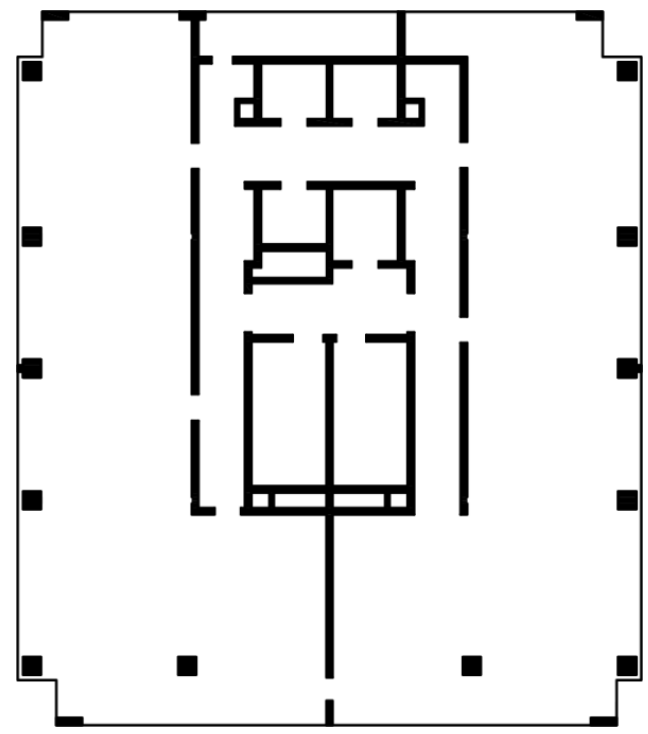

Rys. 6. Rzut układu bez ścian poprzecznych do trzonu budynku

Fig. 6. Floor plan of the scheme without walls perpendicular to core of the building

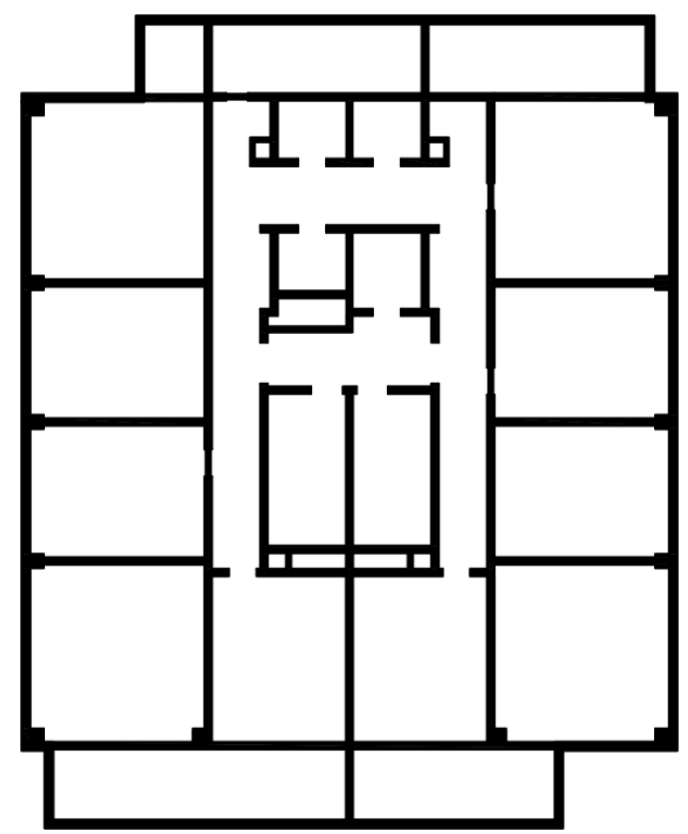

Rys. 7. Rzut kondygnacji technicznej wraz z dodatkowymi ścianami tworzącymi outrigger

Fig. 7. Floor plan of the technical storey with additional walls creating outrigger 


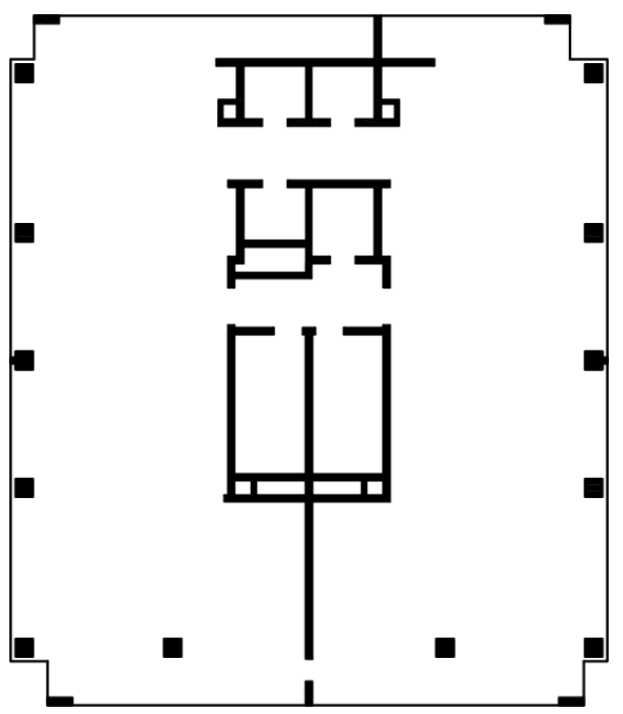

Rys. 8. Rzut układu bez ścian poprzecznych do trzonu budynku oraz ścian do nich prostopadłych

Fig. 8. Floor plan of the scheme without walls perpendicular to core of the building and walls perpendicular to them

Wyniki analizy przedstawiono w tabelach $2-4$. Przykładową deformację układu oraz naprężenia w trzonie budynku umieszczono na rys. 9 i 10.

Tabela 2. Siły w słupach najniższej kondygnacji w zależności od przyjętego wariantu konstrukcyjnego (numeracja słupów wg rysunku 4)

Table 2. Forces in the lowest storey depending on assumed version of structural system (numbering of column acc. to fig. 4)

\begin{tabular}{|l|l|l|l|l|l|l|l|l|}
\hline \multicolumn{2}{|l|}{ Siły w słupach najniższej kondygnacji $[\mathrm{kN}]$} \\
\hline $\begin{array}{l}\text { Schemat } \\
\text { układu: }\end{array}$ & I & II & III & IV & V & VI & VII & VIII \\
\hline Słup 1 & 11197 & 13023 & 10001 & 14044 & 11999 & 13416 & 15395 & - \\
\hline Słup 2 & 15455 & 17751 & 15613 & 9896 & 11447 & 9288 & 14603 & - \\
\hline Słup 3 & 14193 & 16390 & 13035 & 15528 & 14292 & 14626 & 17740 & - \\
\hline Słup 4 & 17541 & 19975 & 17169 & 16749 & 15605 & 16007 & 18851 & - \\
\hline Słup 5 & 10205 & 12480 & 9862 & 11762 & 11589 & 11482 & 15212 & - \\
\hline Słup 6 & 11875 & 13340 & 11800 & 12409 & 12776 & 12444 & 14205 & - \\
\hline Słup 7 & 5617 & 11863 & 10124 & 10995 & 11502 & 10969 & 11578 & - \\
\hline Słup 8 & 7468 & 7557 & 6286 & 7105 & 7165 & 6860 & 6977 & - \\
\hline Słup 9 & 10293 & 7539 & 5267 & 10944 & 10600 & 10146 & 11858 & - \\
\hline Słup 10 & 10542 & 8907 & 7391 & 11234 & 11174 & 10235 & 13841 & - \\
\hline Słup 11 & 8856 & 5901 & 3859 & 10700 & 11317 & 9854 & 14627 & - \\
\hline Słup 12 & 8978 & 8449 & 7225 & 8506 & 8472 & 8096 & 10726 & - \\
\hline
\end{tabular}


Tabela 3. Przemieszczenia wierzchołka budynku w zależności od wariantu konstrukcyjnego

Table 3. Lateral drift depending on assumed version of structural system

\begin{tabular}{|l|l|l|l|l|l|l|l|l|}
\hline $\begin{array}{l}\text { Schemat układu } \\
\text { konstrukcyjnego: }\end{array}$ & I & II & III & IV & V & VI & VII & VIII \\
\hline $\begin{array}{l}\text { Przemieszczenie } \\
\text { wierzchołka bu- } \\
\text { dynku [mm] }\end{array}$ & 73,5 & 47,9 & 75,4 & 111,3 & 116,3 & 106,1 & 207,3 & 374,1 \\
\hline
\end{tabular}

Stosowane w normalizacji ograniczenie wychylenia budynku wynosi $\mathrm{H} / 500$ co daje $272 \mathrm{~mm}$. Przemieszczenie otrzymane dla wersji projektowej wynosi $73,5 / 136000=\mathrm{H} / 1850$.

Tabela 4. Naprężenia w punkcie „A” w narożu ściany trzonu, w zależności od wariantu konstrukcyjnego $[\mathrm{MPa}]$

Table 4. Stresses in point "A" depending on assumed version of structural system

\begin{tabular}{|l|l|l|l|l|l|l|l|l|}
\hline Schemat & I & II & III & IV & V & VI & VII & VIII \\
\hline Naprężenie & 15,51 & 14,82 & 15,14 & 16,93 & 16,65 & 17,33 & 20,72 & 30,71 \\
\hline
\end{tabular}

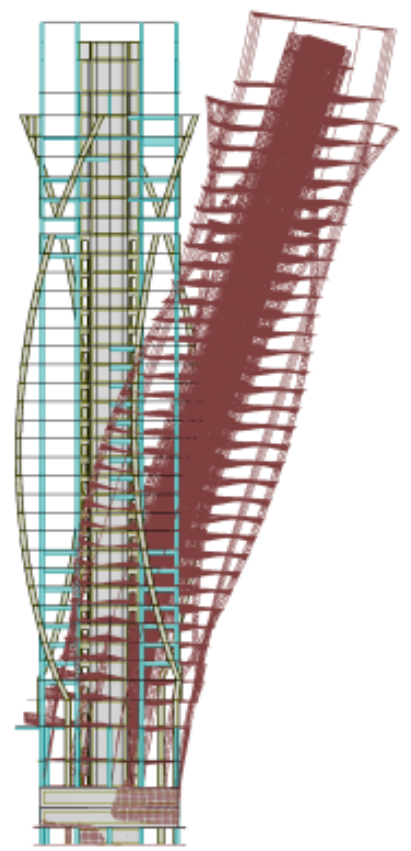

Rys. 9. Deformacja modelu obliczeniowego budynku

Fig. 9. Deflection of numerical model of building 


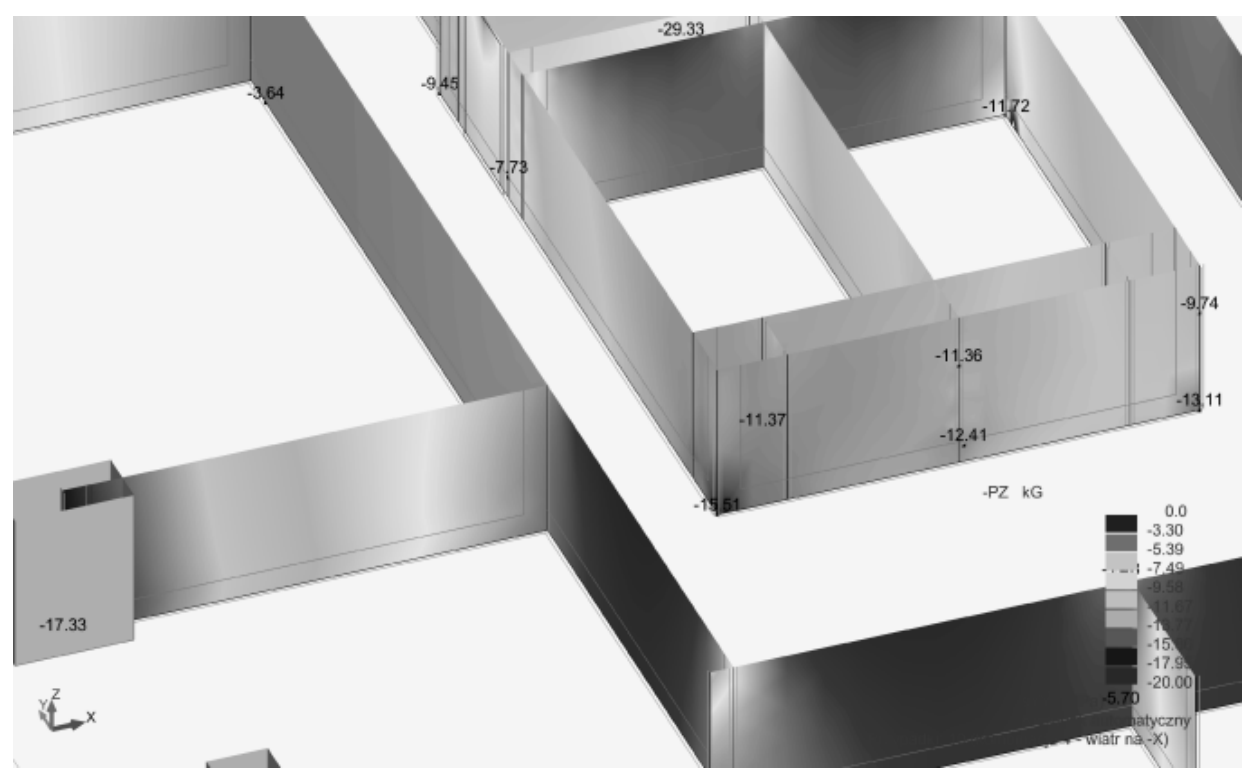

Rys. 10. Mapy naprężeń w trzonie - schemat I

Fig. 10. Stress maps in the core - scheme I

\section{Wnioski}

Przeprowadzona analiza wykazała znaczący udział słupów w przenoszeniu obciążenia poziomego działającego na konstrukcję. Udział ten zmieniał się w zależności od stopnia rozbudowania trzonu, jednak nawet przy braku ścian łączących te elementy konstrukcyjne, w słupach pojawiały się zauważalne siły przy obciążeniach poziomych. Sugeruje to konieczność uwzględniania przy obliczeniach sił wewnętrznych w słupach nie tylko obciążeń grawitacyjnych, ale również wpływu obciążenia poziomego. Usunięcie ścian poprzecznych do trzonu budynku wywołało wyraźny spadek sztywności całego układu, który jedynie w niewielkim stopniu można zniwelować poprzez rozbudowanie outriggera na kondygnacji technicznej. Celem takiego zabiegu jest wciągnięcie słupów do współpracy przy przenoszeniu obciążeń poziomych, jednak w tym wypadku i bez outriggera ta współpraca istnieje, co najlepiej obrazują wyniki analizy schematu VIII, w którym całkowite pozbycie się słupów wywołało prawie 4-krotny wzrost przemieszczenia wierzchołka budynku. Zastosowanie belek obwodowych poskutkowało wyrównaniem naprężeń w płycie, jednak nie miało większego wpływu na sztywność całego budynku. Pozostawienie tylko wewnętrznej części trzonu niemal 3-krotnie obniżyło sztywność budynku. 


\section{Literatura}

[1] Ali M.M., Moon K.S.: Structural Developments in Tall Buildings: Current Trends and Future Prospects, "Architectural Science Review", 2007, nr 50.

[2] Bródka J., Kozłowski A., Stalowe budynki szkieletowe, Oficyna Wydawnicza Politechniki Rzeszowskiej, Rzeszów 2003.

[3] Kapela M., Sieczkowski J., Projektowanie konstrukcji budynków wielokondygnacyjnych, Oficyna Wydawnicza Politechniki Warszawskiej, Warszawa 2003.

[4] Pawłowski A. Z., Cała I., Budynki Wysokie, Oficyna Wydawnicza Politechniki Warszawskiej, Warszawa 2013.

[5] Structural Systems for Tall Buildings, pod redakcją: R. M. Kowalczyk, R. Sinn, M. B. Kilmister. McGaw-Hill, Inc. Singapore 1995.

[6] Taranath B. S., Structural Analysis and Design of Tall Buildings. Steel and Composite Construction, Taylor \& Francis Group, LLC 2012.

[7] http://www.autodesk.pl/products/simulation/features/robot-structuralanalysis/all/gallery-view

\section{ANALYSIS OF LATERAL LOAD-RESISTING SYSTEM OF CONCRETE HIGH-RISE BUILDING}

\section{S u m m a r y}

Lateral load-resisting systems applied nowadays in high-rise buildings have been described with the special emphasis to concrete structure buildings. Using $136 \mathrm{~m}$ high concrete structure building as an example analysis of shaping of lateral system was conducted. In the analysis the following was considered: core shape, wall localization, cooperation of column. Analysis was performed with the use of software Robot.

Keywords: high-rise building, lateral load-resisting system, stiffness of concrete building 